\title{
BAHASA INDONESIA MENUJU BAHASA INTERNASIONAL
}

\section{Tatatan Ekonomi Baru}

Dalam perikehidupan masyarakat Indonesia telah terjadi berbagai perubahan, terutama yang berkaitan dengan tata ekonomi dan politik. Di bidang ekonomi, misalnya, telah terjadi perubahan dalam sistem perdagangan dari perdagangan tradisional ke perdagangan bebas, dari sistem tawar ke sistem harga mati. Situasi itu telah merambah ke kota-kota kecil di Tanah Air. Bahkan, sistem itu telah merambah ke perdagangan eceran (kecil), seperti pasar-pasar/toko kecil (mini market) dan kios-kios barang dan minuman. Selain hilangnya budaya tawar, ada fenomena baru sedang mewabah seolah menandai kelas sosial masyarakat, yaitu belanja secara daring (online), belanja tak perlu keluar rumah cukup memesan secara daring dan barang diantar ke rumah. Kondisi itu mendatangkan pengusaha besar memasuki area perdagangan tradisional, bahkan sejumlah pengusaha besar dari luar Indonesia mendekati pasar-pasar tradisional. Sistem perdagangan pun telah berubah diawali dengan Tata Ekonomi Eropa dan perkembangan di kawasan Asia Tenggara. Kawasan Asia Tenggara ini telah memasuki Masyarakat Ekonomi ASEAN (MEA). Kondisi itu telah menempatkan bahasa asing pada posisi strategis yang memungkinkan bahasa itu memasuki berbagai sendi kehidupan bangsa dan memengaruhi perkembangan bahasa di kawasan negara-negara ASEAN, seperti bahasa Indonesia (Sugono, 2014). Keadaan itu telah membawa perubahan gaya hidup dan perilaku masyarakat dalam bertindak dan berbahasa, khususnya di Indonesia. Misalnya, rasa kebersamaan telah tergeserkan oleh individualisme; interaksi sosial di tempat umum telah kehilangan ruang, seperti pusat belanja yang disebut pasar dahulu menjadi tempat interaksi sosial warga masyarakat. Kini tempat itu telah berganti pasar modern (swalayan) yang tidak memberi peluang terjadinya interaksi sosial, bahkan antara pembeli dan penjual, apalagi dengan pemilik barang dagangan, tidak ada percakapan. Gejala tersebut merupakan indikasi bahwa ruang gerak penggunaan bahasa Indonesia sebagai bahasa pergaulan mengalami pergeseran. Sebaliknya, penggunaan bahasa asing makin memperoleh tempat dalam tatanan kehidupan masa kini.

Pembangunan hotel, permukiman/apartemen, pusat belanja, dan industri modern, serta ruang promosi telah memberi peluang penggunaan bahasa asing, setidaknya dalam pemberian nama hotel, permukiman/apartemen, pusat belanja, merek dagang, dan iklan, bahkan di kalangan pengusaha/pedagang kecil pun turut memarakkan penggunaan bahasa asing tanpa pendampingan bahasa Indonesia. Kini label klasifikasi buku-buku pada rak-rak pajangan di toko buku besar di Jakarta telah berganti bahasa Inggris; sudah tidak ada bahasa Indonesia; bahkan judul buku tertulis dalam bahasa Inggris, padahal isi buku itu tertulis dalam bahasa Indonesia. Seperti halnya media televisi, nama mata acara dalam bahasa 
Inggris, sementara acara itu berbahasa Indonesia (Sugono, 2017). Tampaknya, pemberlakuan pasar bebas ASEAN dan globalisasi telah mengubah pola pikir dari keperluan nasional ke kepentingan regional Asia Tenggara dan kepentingan mitramitra ASEAN. Pada sisi lain, investasi dan pengembangan prasarana telah memasukkan tenaga kerja asing tanpa penguasaan bahasa Indonesia. Padahal, pada masa perjuangan kemerdekaan, bahasa Indonesia memiliki peran sangat strategis dalam perkembangan kehidupan masyarakat Indonesia. Penggunaan bahasa Indonesia dalam penerbitan bacaan rakyat/sastra (Balai Pustaka 1920-an) dan dalam buku-buku serta dalam media cetak (koran dan majalah) pada era itu betul-betul telah memperluas persebaran penggunaan bahasa Indonesia ke berbagai lapisan masyarakat di Indonesia, bahkan popularitas publikasi Balai Pustaka tersebut sampai di Malaysia, Singapura, dan Brunei Darussalam.

Sebagaimana paparan di atas, bahasa Indonesia memainkan peran dalam perjuangan kemerdekaan bangsa Indonesia, penyatuan berbagai ragam kehidupan sosial budaya suku bangsa ke dalam satu kesatuan bangsa, pencerdasan kehidupan bangsa, dan pembawa perubahan menuju peradaban maju. Maka, pendidikan bahasa Indonesia memiliki peran strategis dalam membangun kecerdasan dan kepribadian anak bangsa, bahkan pada masa pascakemerdekaan bahasa Indonesia turut membentuk karakter sebagai bangsa Indonesia yang bertumpu pada peradaban suku bangsa di Indonesia. Sebelum itu, telah tumbuh dan berkembang karakter suku bangsa sebagai bagian dari peradaban bangsa di kawasan nusantara ini. Peran bahasa Indonesia dalam pembangunan karakter bangsa itu makin kukuh ketika bahasa Indonesia dinyatakan sebagai bahasa negara (Pasal 36c UndangUndang Dasar Negara Kesatuan Republik Indonesia 1945). Selain sebagai bahasa dalam menjalankan pemerintahan dan kenegaraan, bahasa Indonesia menjadi bahasa pengantar pendidikan bagi anak Indonesia. Kebersamaan dalam perjuangan kemerdekaan itu memberikan kekuatan kepada bahasa Indonesia untuk memainkan peran dalam pembangunan ke-Asia-Tenggara-an dalam memasuki Masyarakat Ekonomi ASEAN.

\section{Situasi Kebahasan di Kawasan Asia Tenggara}

Sepuluh negara anggota ASEAN masing-masing memiliki bahasa resmi negara. Brunei Darussalam memiliki bahasa resmi bahasa Melayu; Filipina bahasa Filipino; Indonesia bahasa Indonesia; Kamboja bahasa Khmer; Laos bahasa Lao; Malaysia bahasa Melayu; Singapura bahasa China Mandarin, bahasa Melayu, Tamil, Inggris; Thailand bahasa Thai; dan Vietnam bahasa Vietnam. Selain bahasa resmi, hampir setiap negara memiliki bahasa lokal atau bahasa daerah (746 di Indonesia). Keberagaman bahasa itu kemungkinan menjadi bahan pertimbangan para pendiri ASEAN memilih bahasa Inggris sebagai bahasa resmi perhimpunan itu. Kalau ASEAN merupakan kerja sama dalam berbagai sektor, 
bagaimana dengan MEA yang merupakan kerja sama sektor ekonomi. Apakah mengikuti kebijakan ASEAN dengan menetapkan bahasa Inggris sebagai satusatunya bahasa resmi organisasi itu? Ataukah ada alternatif selain bahasa Inggris ada bahasa lain yang memiliki kemampuan untuk itu.

Kerja sama sektor ekonomi ini lebih berkaitan dengan persoalan investasi, usaha, perdagangan, tenaga kerja, dan sebagainya yang lebih melibatkan pelaku dan komsumen kalangan khalayak daripada kalangan deplomat. Interaksi komunitas MEA lebih pada bahasa kerja masyarakat daripada bahasa deplomasi. Dasar pemikiran itu memberi peluang besar bagi penggunaan bahasa yang hidup dalam masyarakat negara-negara anggota organisasi itu. Dilihat dari ketersebaran penutur di negara-negara Asia Tenggara, bahasa Indonesia/Melayu memiliki ketersebaran wilayah penutur di tujuh negara dan menjadi bahasa resmi di tiga negara anggota MEA.

Adapun ditinjau dari jumlah penutur dan luas wilayah penggunaan bahasa, bahasa Indonesia dituturkan oleh (sekitar) 240 juta penduduk dengan bentangan luas wilayah penutur bahasa dari batas negara PNG, Samudera Hindia, Selat Malaka (Malaysia, Singapura, Brunei Darussalam), Laut Natuna Utara/Laut Cina, Samudera Pasifik, dan Perbatasan Filipina. Atas dasar pertimbangan jumlah penutur besar dan ketersebarluasan wilayah bahasa, sangatlah wajar jika bahasa Indonesia memiliki peluang menjadi salah satu bahasa resmi dalam kerja sama MEA.

Atas pertimbangan pemikiran di atas, bahasa Indonesia memiliki peluang menjadi salah satu bahasa resmi MEA.

\section{Potensi Bahasa Indonesia}

Sebagai bahasa perhubungan luas di kawasan Asia Tenggara, bahasa Indonesia memiliki dua kekuatan, yaitu kekuatan kelinguistikan dan kekuatan historis.

\subsection{Kekuatan Kelinguistikan}

Bagaimana kesiapan dari sudut potensi kelinguistikan bahasa Indonesia, misalnya kemampuan daya ungkap (kosakata) bidang agama, ilmu, teknologi, pertanian, kehutanan, ekonomi/bisnis, seni, dan sosial/budaya masyarakat. Dalam hal sosial budaya masyarakat, Indonesia memiliki pengalaman bagaimana mengatasi perbedaan bahasa, sosial, budaya, etnis, gender, dan kesenjangan lain. Di samping itu, keberadaan 746 bahasa (daerah) di wilayah Indonesia sudah merupakan indikasi adanya keragaman permasalahan bahasa ibu, bahasa daerah, bahasa kewilayahan, bahasa persatuan, bahasa nasional, bahasa resmi negara, dan sebagainya. Sejarah perjuangan kemerdekaan Indonesia memberi pelajaran berharga bagi bangsa Indonesia (Sumpah Pemuda 28 Oktober 1928). Atas dasar 
semangat perjuangan kemerdekaan, bangsa Indonesia dapat mengatasi permasalahan tersebut, antara lain melalui kebijakan bahasa atau waktu itu dikenal dengan sebutan politik bahasa, yaitu pengakuan dan pemertahanan bahasa daerah, pemerkukuh bahasa Indonesia sebagai bahasa persatuan, bahasa nasional, dan bahasa negara, serta peluang pembelajaran dan penguasaan bahasa asing sesuai dengan keperluan. Adapun ihwal kemampuan daya ungkap, bahasa Indonesia telah memiliki 100,000 kata umum (Kamus Besar Bahasa Indonesia) dan 410.000 istilah berbagai bidang ilmu (agama, kimia, matematika, biologi, fisika, kedokteran, hukum, psikologi, politik, pertanian, kehutanan, pendidikan, linguistik, sastra, teknologi komunikasi, dan sebagainya. Hasil pengembangan peristilahan itu dipublikasikan dalam bentuk kamus bidang ilmu, glosarium istilah, dan media daring (online). Demikian juga bahasa Melayu, melalui kerja sama Majelis Bahasa Brunei Darussalam-Indonesia-Malaysia (MABBIM), secara bersama-sama Indonesia, Brunei Darussalam, dan Malaysia mengembangkan peristilahan dalam bahasa Indonesia/Melayu. Melalui kerja sama itu, perbedaan peristilahan bidang ilmu (modern) antara bahasa Indonesia dan bahasa Melayu makin kecil, kecuali peristilahan yang telah digunakan sejak masa lalu sebelum kerja sama itu berlangsung. Bagaimana dengan kemampuan bahasa Indonesia dalam sistem ketatabahasaan dari sudut pandang ketaatasasan sistem/kaidah sebagai bahasa ilmu, teknologi, dan seni/budaya, serta sebagai bahasa pergaulan?

Kalau dari sisi daya ungkap bahasa Indonesia telah memiliki lima ratus ribu lebih kata umum dan istilah yang terkodifikasi dalam Kamus Besar Bahasa Indonesia, Kamus Dewan, dan Kamus Bahasa Melayu Nusantara, serta glosarium dan kamus bidang ilmu. Bagaimana dengan kaidah bahasa dalam sistem tulis (ejaan), pembentukan kata, kalimat, paragraf, dan sebagainya? Untuk sistem tulis, bahasa Indonesia telah memiliki keselarasan penggunaan ejaan yang sama sejak penandatanganan Komunike Bersama (1972) antara Indonesia dan Malaysia, disusul dengan pendirian Majelis Bahasa Indonesia-Malaysia (MBIM) sebagai wadah kerja sama kebahasaan. MBIM, antara lain, menangani pengembangan peristilahan bersumber dari bahasa asing ke dalam bahasa Indonesia dengan melibatkan pakar bidang ilmu di kedua negara. Pada tahun 1985 Brunei Darussalam masuk anggota sehingga forum kerja sama itu menjadi Majelis Bahasa Brunei Darussalam-Indonesia-Malaysia (MABBIM), Singapura sebagai pemerhati yang senantiasa hadir dalam persidangan dan seminar setiap tahun. Permasalahan pengembangan (bahasa) dan pemasyarakatannya serta ihwal pembinaan (penutur) senantiasa dibahas dalam seminar yang diadakan sempena sidang majelis tersebut. Kerja sama itu telah menghasilkan kesepakatankesepakatan ihwal pembentukan kata/istilah dalam bahasa Indonesia dan bahasa Melayu selaras, kecuali kaidah-kaidah yang telah memasyarakat sejak dahulu. 
Atas dasar pemaparan kerja sama bahasa Indonesia dan bahasa Melayu tersebut di atas, bahasa Indonesia memiliki potensi menjadi salah satu bahasa resmi perhimpunan MEA.

\subsection{Kekuatan Historis}

Dari sudut pandang kesejarahan bahasa Melayu sudah menjadi lingua franca di nusantara ini dan bahkan telah dipelajari bangsa di luar negara anggota MEA, dengan bukti dokumen Daftar Kata Cina-Melayu (berisi 500 lema) pada permulaan abad ke-15 dan Daftar kata Italia-Melayu (1522) disusun oleh Pigafetta (Kridalaksana dalam Kamus Besar Bahasa Indonesia Pusat Bahasa, 2015). Selain menjembatani antarbangsa (China dan Italia) tersebut, bahasa Melayu juga berfungsi sebagai bahasa perhubungan dalam persebaran Islam di kawasan nusantara. Saat bangsa Eropa menjelajah nusantara dalam perdagangan rempah dsb., bahasa Melayu pun menjadi sarana komunikasi antara pendatang dan penduduk setempat. Pada masa penjajahan, bahasa itu juga digunakan oleh Pemerintah Belanda sebagai bahasa perhubungan dengan rakyat Indonesia. Adapun pada masa perjuangan kemerdekaan bangsa Indonesia, bahasa itu mampu menyatukan masyarakat yang berbeda latar belakang sosial, budaya, bahasa, etnis, dan geografi ke dalam satu kesatuan tanah air, bangsa, dan bahasa persatuan. Demikianlah dalam sejarah perjalanan waktu, bahasa Melayu telah memainkan peran sebagai bahasa perhubungan yang melintasi antaretnis dan antarbangsa serumpun di nusantara serta antarbangsa di luar kawasan nusantara.

Atas dasar pertimbangan kekuatan kelinguistikan dan kekuatan historis, bahasa Indonesia memiliki peluang peningkatan fungsi sebagai bahasa pergaulan dan bahasa perdagangan antarbangsa di Asia Tenggara. Kondisi itu akan mempercepat persebaraan bahasa Indonesia di kawasan Asia Tenggara maka peluang besar bahasa itu menjadi salah satu bahasa resmi MEA. Semua itu disertai dengan upaya diplomasi menjadikan bahasa Indonesia sebagai salah satu bahasa resmi MEA.

\section{Strategi di Kawasan Asia Tenggara}

Dalam tatanan kehidupan global persaingan antarbangsa--terutama dalam bidang ekonomi/perdagangan, investasi, dan politik--makin menonjol. Untuk menyiasati persaingan dengan negara maju dan negara besar, negara-negara berkembang dan negara kecil, yang secara sosiologis geografis memiliki kedekatan, membangun kerja sama agar memiki kekuatan seimbang dalam persaingaan dengan negara maju dan negara besar. Negara-negara di Asia Tenggara telah memiliki forum kerja sama dalam ASEAN, kemudian lebih khusus membentuk Masyarakat Ekonomi ASEAN (MEA) untuk menampung kerja sama bidang ekonomi/bisnis. Bidang itu memiliki cakupan yang luas; misalnya sektor 
perdagangan akan melibatkan investasi, industri, pemasaran, dan tenaga kerja. Selain itu, kerja sama ekonomi berhubungan erat dengan kondisi sosial budaya masyarakat negara-negara anggota. Kemajuan ilmu dan teknologi sebagai sarana pencapaian kemakmuran masuk dalam cakupan kerja sama ini juga. Keberhasilan kerja sama dalam mencapai kemajuan dan kemakmuran bersama berkait erat dengan kebijakan politik dan strategi deplomasi. Semua kerja sama tersebut memerlukan sarana pikir, sarana ekspresi, dan sarana komunikasi yang sangat efektif, yaitu bahasa yang dapat diproduksi dan dipahami oleh komunitas masyarakat Asia Tenggara, seperti ASEAN ataupun MEA. Sebagaimana paparan pada sesi-sesi di atas, bahasa Indonesia/Melayu memiliki potensi sebagai bahasa perhubungan di komunitas masyarakat Asia Tenggara, baik kekuatan kelinguistikan maupun kekuatan kesejarahan bahasa itu dalam interaksi antarbangsa. Di samping itu, bahasa Indonesia memiliki jumlah penutur besar dan wilayah penggunaan bahasa itu seluas wilayah Indonesia dan wilayah Malaysia, Brunei, Singapura, serta sebagian wilayah Thailand dan sebagian wilayah Filipina. Atas dasar pemikiran tersebut forum ini ingin memajukan bahasa Indonesia sebagai salah satu bahasa resmi internal perhimpunan bangsa-bangsa Asia Tenggara. Adapun kerja sama Perhimpunan Bangsa Asia Tenggara dengan negara maju, seperti Jepang, Korea, Tiongkok, India, dan Perhimpunan Bangsa Eropa menggunakan bahasa Inggris atau bahasa masing-masing, yaitu bahasa perhimpunan bangsa Asia Tenggara (Indonesia/Melayu) dan bahasa negara yang bersangkutan dengan penerjemah masing-masing. Kebijakan itu dimajukan atas pertimbangan saat ini (bahkan sudah sejak pertengahan abad ke-20 lalu) bahasa Jepang, bahasa Korea, bahasa Mandarin, bahasa Arab, bahasa Inggris, bahasa Jerman, dan bahasa Prancis telah dipelajari dan bahkan menjadi bidang studi di perguruan tinggi di Indonesia.

Bagaimana dengan persebaran bahasa Indonsia di luar kawasan Asia Tenggara? Dengan perkataan lain, bagaimana potensi dan peluang bahasa Indonesia menuju dunia internasional?

\section{Strategi Persebaran Bahasa Indonesia di Dunia Internasional}

Berdasar pertimbangan berbagai latar belakang permasalahan dan pemikiran tersebut di atas, perlu dibahas masalah strategi peningkatan fungsi bahasa Indonesia sebagai bahasa internasional secara bertahap, sistematis, dan berkelanjutan (Undang-Undang No. 24 Tahun 2009). Secara bertahap memiliki makna 'upaya pemasyarakatan bahasa Indonesia dilakukan di dalam wilayah negara-negara Asia Tenggara, ke negara-negara mitra ASEAN (Jepang, Korea, Tiongkok), Australia, India, Timur Tengah, Afrika, Uni Eropa, dan Amerika. Bertahap juga dimaksudkan dari jenjang atau tingkat pemula, madya, lanjut, dan profesi dalam pembelajaran bahasa Indonesia bagi penutur asing (BIPA) pada 
bidang/ranah diplomat, bisnis/perdagangan, hukum, kesehatan, pariwisata, industri, dan sebagainya. Bersistem maksudnya 'kebijakan itu dilakukan dengan menganut prinsip belajar-mengajar secara komprehensif dan aplikatif dengan sasaran anak-anak (sekolah dasar), remaja (sekolah menengah), pemuda/pemudi (perguruan tinggi), hingga generasi pelaku di bidang politik/deplomasi, seni/budaya, ilmu (pengetahuan), teknologi, dan bidang ekonomi/bisnis, pariwisata, tenaga kerja, dan sebagainya melalui berbagai jalur.' Berkelanjutan memiliki makna 'upaya dilakukan terus secara berkesinambungan dan konsisten, bahkan tanpa henti walau sudah dicapai sasaran peningkatan fungsi bahasa Indonesia ke seluruh kawasan dunia. Strategi itu dijalankan karena perkembangan ilmu dan teknologi serta media sosial akan memengaruhi perkembangan ekonomi/perdagangan, politik, budaya, dan tata kehidupan dalam memenuhi tuntutan penginternasionalan bahasa Indonesia.

Lembaga pemerintah yang menangani ke-BIPA-an ini adalah Pusat Pengebangan Strategi dan Diplomasi Kebahasaan, Badan Pengembangan dan Pembinaaan Bahasa, Kementerian Pendidikan dan Kebudayaan. Sementara itu, organisasi yang menangani ke-BIPA-an itu ialah Afiliasi Pegiat dan Pengajar Bahasa Indonesia bagi Penutur Asing (APPBIPA) yang baru saja (12-14 Oktober 2017) menyelenggarakan Konferensi Internasional di Batu, Malang, Jawa Timur yang dihadiri penyelenggara pembelajaran BIPA di dalam dan dari luar negeri.

Kondisi persebaran ke-BIPA-an saat ini sebetulnya telah meliputi ke lima benua. Mulai dari Asia Tenggara Ke-BIPA-an diselenggarakan di Thailand, Kamboja, Laos, Filipina, Malaysia, Singapura, Timor Leste, dan Vietnam. Di negara-negara tersebut terdapat 48 lembaga penyelenggara BIPA dengan 84 tenaga pengajar dan 14.053 mahasiswa/siswa. Data sementara ini memperlihatkan bahwa di Australia pembelajaran BIPA diselenggarakan di sejumlah universitas dan lembaga (termasuk Balai Bahasa di Perth) serta di sejumlah sekolah lanjutan tingkat atas, bahkan di sekolah dasar di wilayah Australia Utara. Sementara itu, di Jepang pembelajaran BIPA diselenggarakan juga di sejumlah perguruan tinggi dan lembaga kursus. Demikian juga di Beijing, Guangzou dan Hongkong; Korea Selatan; Rusia, Belanda, Jerman, Prancis, Italia, Inggris, Azar Baijan, Mesir; dan Amerika Serikat, Canada, Amerika Selatan.

Langkah yang perlu ditempuh adalah melakukan penelitian ke-BIPA-an di semua wilayah. Untuk keperluaan perencanaan ke depan, sangat diperlukan penelitian ke-BIPA-an, baik lembaga penyelenggara, jumlah guru/pengajar, mahasiswa/siswa, sarana/prasarana maupun pelaksanaan pembelajaran.

Penggarapan perencanaan ke depan perlu segera disiapkan pembelajaran melalui daring (online) agar penyelenggara BIPA di seluruh wilayah di dalam ataupun di luar negeri dapat berinteraksi dengan Pusat (Badan Bahasa dan APPBIPA) dan Wilayah serta para penyelenggara dapat saling berbagi pegalaman 
dan betukar bahan ajar. Selain itu, di sejumlah wilayah di luar negeri perlu dibangun Pusat Studi Indonesia (apakah dinamai Rumah atau Wisma Indonesia) yang bertempat di KBRI atau berdiri sendiri di bawah naungan KBRI. Di situlah tempat para mahasiswa/siswa belajar seolah berada di Indonesia mini.

Selain strategi persebaran bahasa Indonesia menuju dunia internasional, penggunaan bahasa Indonesia dalam berbagai ranah kehidupan di seluruh wilayah tanah air, sebagaimana paparan pada awal makalah ini, harus dibenahi demi peningkatan sikap positif masyarakat terhadap bahasa kebangsaan di bumi pertiwi. Oleh karena itu, perjuangan pada semua lini harus dijalankan, baik persebaran BIPA di luar negeri maupun penguatan bahasa Indonesia di seluruh wilayah Indonesia, "berjaya di bumi pertiwi, bermartabat di negara sahabat".

\section{DAFTAR PUSTAKA}

Alwi, Hasan dan Dendy Sugono (Ed.). 2000. Politik Bahasa. Jakarta: Pusat Bahasa.

Alwi, Hasan, Dendy Sugono, dan A. Rozak Zaidan. (Ed.) 2000. Bahasa Indonesia dalam Era Program Globalisasi. Jakarta: Pusat Bahasa.

Brown, H. Douglas. 2007. Terjemahan. Noor Cholis dan Yusi Avianto Perianom. Prinsip Pembelajaran dan Pengajaran Bahasa.

Kaswanti Purwo, Bambang. 2002. "Perkembangan Pengajaran Bahasa". Dalam Hasan Alwi dan Dendy Sugono (Ed.) Telaah Bahasa dan Sastra. Jakarta: Penerbit Obor dan Pusat Bahasa.

Moeliono, Anton M. 2000. "Kedudukan dan Fungsi Bahasa Indonesia dalam Era Globalisasi” Dalam Hasan Alwi, Dendy Sugono, dan A. Rozak Zaidan (Ed.). Bahasa Indonesia dalam Era Globalisasi. Jakarta: Pusat Bahasa.

Pusat Bahasa.2008. Lentera Inonsia I da II. Jakarta.

Syamsuddin, AR dan Vismaia S. Damaianti. 2006. Metode Penelitian Pendidikan Bahasa. Bandung: PT Remaja Rosdakarya.

Sugono, Dendy. (Ed.) 2003. Bahasa Indonesia Menuju Masyarakat Madani. Jakarta: Penerbit Progres.

--------. 2004. "Strategi Perancangan Pengembangan dan Pembinaan Bahasa Indonesia" Makalah Kongres Bahasa Utama Dunia. Kuala Lumpur, 5-8 Oktober 2004.

2005. "Prospek Bahasa Indonesia dalam Era Globalisasi" Dalam Seminar Pengajaran Bahasa Indonesia di Australia. Perth, Australia. 
2014. Peran dan Kekuatan Bahasa Indonesia dalam Industri Kreatif Kebahasaan. Jakarta: Badan Bahasa dan Lembaga Ilmu Pengetahuan Indonesia

2017. "Pembelajaran Bahasa Indonesia bagi Penutur Asing di Asia Tenggara.” Batu, Malang: Konferensi Internasional X BIPA. 